\title{
Salt Weathering of Natural Stone: A Review of Comparative Laboratory Studies
}

\author{
Carlos Alves $^{1, *(\mathbb{D})}$, Carlos A. M. Figueiredo ${ }^{2}{ }^{\mathbb{D}}$, Jorge Sanjurjo-Sánchez ${ }^{3}$ and Ana C. Hernández ${ }^{3}$ \\ 1 LandS/Lab2PT-Landscapes, Heritage and Territory Laboratory (FCT-UIDB/04509/2020), \\ Earth Sciences Department, School of Sciences, University of Minho, 4710-057 Braga, Portugal \\ 2 CERENA-Centre for Natural Resources and the Environment, FCT-UIDB/04028/2020, DEcivil, \\ Instituto Superior Técnico, University of Lisbon, 1049-001 Lisbon, Portugal; carlos.m.figueiredo@ist.utl.pt \\ 3 University Institute of Geology, University of A Coruña, ESCI, Campus de Elviña, 15071 A Coruña, Spain; \\ jorge.sanjurjo.sanchez@udc.es (J.S.-S.); ana.cristina.hernandez.santome@udc.es (A.C.H.) \\ * Correspondence: casaix@dct.uminho.pt
}

\section{check for} updates

Citation: Alves, C.; Figueiredo, C.A.M.; Sanjurjo-Sánchez, J.; Hernández, A.C. Salt Weathering of Natural Stone: A Review of Comparative Laboratory Studies. Heritage 2021, 4, 1554-1565. https:// doi.org/10.3390/heritage4030086

Academic Editors:

Miguel Gomez-Heras, Jorge Feijoo,

Monica Alvarez de Buergo and

Rafael Fort

Received: 28 June 2021

Accepted: 30 July 2021

Published: 3 August 2021

Publisher's Note: MDPI stays neutral with regard to jurisdictional claims in published maps and institutional affiliations.

Copyright: (C) 2021 by the authors Licensee MDPI, Basel, Switzerland. This article is an open access article distributed under the terms and conditions of the Creative Commons Attribution (CC BY) license (https:/ / creativecommons.org/licenses/by/ $4.0 /)$.

\begin{abstract}
Natural stone is an important component of historical heritage (buildings and art objects such as sculptures or rock engravings), and it is still widely used in contemporary works. Soluble salts are the main erosive agent in the built environment, and we review here comparative studies that subject the same rock type to testing with different salt solutions. The results mostly support the accepted notion of the major impact of sodium sulphate, although there are some exceptions. The effects of sodium chloride and calcium sulphate deserve specific discussion given field information on the relevance of these specific salts in the built environment. We relate the information collected to the issues of risk assessment (considering both geochemical conditions and salt effects) and conservation interventions (highlighting the interest of tests that do not produce damage to susceptible materials) and present some methodological suggestions to avoid a case study culture.
\end{abstract}

Keywords: water-stone interaction; stone erosion; laboratory simulation; hazards studies; materials conservation; replication; testing methodology

\section{Introduction}

Natural stones are an important component of the historical and contemporary anthropogenic environment (and, certainly, will be materials used in future structures), with diverse types of applications, from pavements and walls to statuary, both indoors and outdoors. In the anthropogenic environment, they are exposed to diverse agents that promote alterations, and many of the effects resulting from the pollutants could be affected by the modifications associated with climate change (see review in Bertolin [1]).

The interaction between natural stone and the pollutants in the anthropogenic environment can result in a great diversity of features, from simply causing changes in surface color and texture to erosive situations that lead to material loss and sometimes the loss of cultural information (engravings, ornamental details, etc.).

Soluble salts have been frequently associated with stone decay at least since the times of Herodotus, who remarked that the pyramids were "being eaten away" by salts [2]. The widespread occurrence of soluble salts and their frequent erosive impact make them the main hazard for natural stone in the built environment. Soluble salts can have diverse sources (see, for example, [3-6]), including sea spray, anthropogenic air pollution, road de-icing, organic sources (including wastes from humans and other animals) and also building materials. There are several reviews regarding saltweathering processes of rocks and stones and the factors that control their impact [3,5-10].

Soluble salts can contribute to diverse coatings such as the well-recognized efflorescences (white surficial occurrences, illustrated in Figure 1). While efflorescences and other 
surficial effects related to salt crystallization (such as black crusts) can have an aesthetic impact, we will focus on the erosive effects of soluble salts (illustrated in Figure 1).

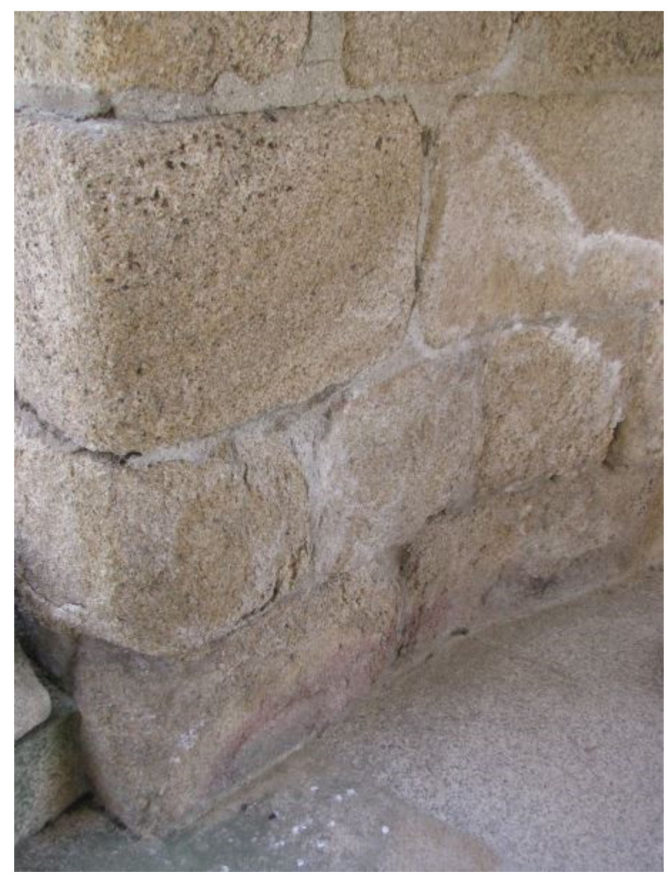

Figure 1. Salt efflorescences (whitish powder) and erosive effects (leading to rounding) on granitic stones of a window from a historical structure in the town of Chaves (Portugal).

Salt weathering can be assessed through laboratory tests and several proposals have been made (for a recent review, see Lubelli et al. [11]) regarding variables such as specimen geometric characteristics (shape and size), conditions for pollutant access (surface deposition, total and partial immersion - the latter attempting to reproduce the frequent situation where salt solutions migrate by capillarity) and climatic conditions (temperature and air moisture). In the assessment of the erosive effects of salts, mass evolution seems to be the most frequent procedure, as it is a reproducible, objectively measurable parameter. However, as is illustrated in Figure 2 (whitish powder), for the case of salt crystallization, it has the disadvantages that it could be disturbed by salt accumulation in porous media (which promotes mass increase) and that it does not reflect the erosion patterns. Visual observation is an important feature, but it is complex to convey in an objective, simple way. Many other procedures have been proposed by diverse authors (some examples can be seen in the reviews mentioned above). Other techniques can be used, such as scanning electron microscopy (SEM), to assess the effects of salt crystallization on the structure of the stone and variations in physical properties.

The main goal of the present work is to review studies that allow the comparison of data from different salt solutions, including solutions of one salt and salt mixtures, applied on the same rock material and under the same testing conditions (in each study). In this way, it will be possible to assess the impact (and hazard level) of different salt solutions. Among the diverse studies considered, there are diverse options regarding testing conditions in terms of specimens' imbibition and salt crystallization conditions. However, the analysis is focused on the comparison of results within the same conditions using different salt conditions. We have focused on studies with natural stone and a complementary goal concerns the assessment of the lithological diversity of the materials studied. We focused on and highlighted information concerning the erosive effects of salt solutions, especially mass loss, which constitute quantitative evidence of the decay effects promoted by the salt solutions. After the presentation of the data collected in the next section, this work considers some specific salts that are especially relevant due to their frequency, presents 
some comments regarding the relevance of field studies and discusses these results in the more global context of reproducibility and case studies.

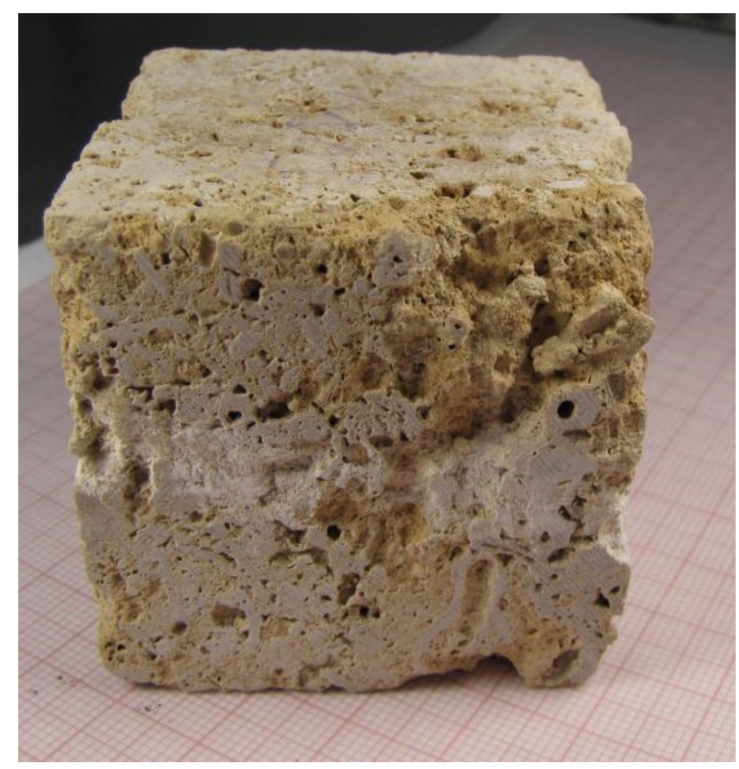

Figure 2. Limestone (travertine) after cycles of salt crystallization with sodium sulphate solutions (note the accumulation of salt efflorescences and the existence of irregular erosion patterns in relation to the shape of the specimen and the rock texture).

\section{Comparison of the Effects of Salt Solutions}

In their "opus magnum" about salt weathering, Goudie and Viles [5] review some previous studies that tested the effects of diverse salt solutions on the same materials. As general trends of their review, these authors highlighted the following points:

- Sodium sulphate, sodium carbonate and magnesium sulphate generally were effective in provoking erosive effects;

- Sodium nitrate had marked erosive effects in some cases but not in others;

- Sodium chloride and calcium sulphate were relatively ineffective in terms of causing erosion.

A more recent publication (Yu and Oguchi [12]), besides presenting the results of testing on diverse rocks, also reviewed previous works and found that sodium sulphate was the most effective in causing degradation of the specimens in most of the studies considered (seven out of 10 studies considered), with the following exceptions:

- A study with granites by Birot from 1954, where the rank was headed by sodium hyposulphite (the only reference that we found to testing with this solution), followed by sodium carbonate, sodium sulphate and sodium chloride;

- A study with sandstones by Goudie from 1986 states that sodium carbonate and magnesium sulphate have a greater impact than sodium sulphate (which was followed by sodium chloride, sodium nitrate and calcium sulphate);

- $\quad$ From 1988, the study by Smith and McGreevy on sandstone indicated higher alteration for magnesium sulphate than sodium sulphate (which was followed by $10 \%$ magnesium sulphate, saturated sodium chloride and $10 \%$ sodium chloride).

In the studies reviewed by these authors, sodium chloride was the least effective salt in causing damage in almost all the studies that included this salt, excepting the study by Cooke in 1979, where sodium chloride, while being clearly less effective than sodium sulphate, was more effective than calcium sulphate and sodium nitrate, and the study by Kwaad in 1970, where calcium sulphate was placed below sodium chloride.

The results of other studies that compared the effects of tests with different salt solutions are presented in three tables regarding size and organization: 
- Table 1, which considers studies with solutions of a given salt (including the experimental results from Yu and Oguchi [12]);

- Table 2, with studies comparing seawater and other salt solutions (including other natural solutions);

- Table 3, presenting studies of salt mixtures and other salt solutions.

Table 1. Analysis of comparative studies of salt crystallization tests using different salts (on the same rock type).

\begin{tabular}{|c|c|c|c|}
\hline Ref. & Rock Types & Solutions & Comparison \\
\hline $\begin{array}{c}\text { Yu and } \\
\text { Oguchi [12] }\end{array}$ & $\begin{array}{l}\text { Sedimentary carbonate } \\
\text { rocks, sandstone, granite, } \\
\text { pyroclastic rocks and } \\
\text { lavic rocks }\end{array}$ & $\begin{array}{l}\text { Magnesium sulphate, } \\
\text { sodium carbonate, } \\
\text { sodium sulphate }\end{array}$ & $\begin{array}{l}\text { In general, sodium sulphate caused higher mass loss, } \\
\text { with some exceptions: } \\
\text { - a sandstone presented significant higher mass loss } \\
\text { for magnesium sulphate (around } 64 \% \text { ) while sodium } \\
\text { sulphate and sodium carbonate caused similarly low } \\
\text { mass loss (below } 2.1 \% \text { ); } \\
\text { - sodium carbonate caused higher loss in a limestone } \\
\text { but mass loss values were below } 1.2 \% \text {. }\end{array}$ \\
\hline Heidari et al. [13] & Limestone & $\begin{array}{l}\text { Magnesium sulphate, } \\
\text { sodium sulphate }\end{array}$ & $\begin{array}{c}\text { Minor mass loss (up to } 0.6 \% \text { ) for sodium sulphate } \\
\text { with clear erosion and negligible for magnesium } \\
\text { sulphate (up to } 0.03 \% \text { ). }\end{array}$ \\
\hline $\begin{array}{c}\text { Sato and Hattanji } \\
{[14]}\end{array}$ & $\begin{array}{l}\text { Pyroclastic rocks, } \\
\text { sandstone }\end{array}$ & $\begin{array}{l}\text { Magnesium sulphate, } \\
\text { sodium chloride, } \\
\text { sodium sulphate }\end{array}$ & $\begin{array}{l}\text { While in the wetting-drying experiments, } \\
\text { magnesium sulphate caused the worst effects } \\
\text { followed by sodium sulphate, for relative humidity } \\
\text { variations, the worst effects (including the total } \\
\text { destruction of one of the sandstone types) were } \\
\text { observed for sodium chloride, followed by } \\
\text { magnesium sulphate (sodium sulphate effects were } \\
\text { almost limited to efflorescences). }\end{array}$ \\
\hline $\begin{array}{c}\text { Çelik and Aygün } \\
\text { [15] }\end{array}$ & $\begin{array}{c}\text { Lavic rock, pyroclastic } \\
\text { rocks }\end{array}$ & $\begin{array}{l}\text { Sodium chloride, } \\
\text { sodium sulphate }\end{array}$ & $\begin{array}{l}\text { Sodium sulphate caused higher mass loss, up to } \\
\text { around } 70 \% \text { (sodium chloride was below } 3 \% \text { but } \\
\text { caused breaking in one of the rock types). }\end{array}$ \\
\hline Derluyn et al. [16] & Limestone & $\begin{array}{l}\text { Sodium chloride, } \\
\text { sodium sulphate }\end{array}$ & $\begin{array}{l}\text { Sodium chloride solutions caused cracking, which } \\
\text { was not observed in limestone specimens tested } \\
\text { with sodium sulphate. }\end{array}$ \\
\hline $\begin{array}{c}\text { Torabi-Kaveh et al. } \\
\text { [17] }\end{array}$ & Limestone & $\begin{array}{l}\text { Magnesium sulphate, } \\
\text { sodium sulphate }\end{array}$ & Negligible mass loss for both salts (up to $0.1 \%$ ). \\
\hline Çelik and Sert [18] & Pyroclastic rocks & $\begin{array}{l}\text { Magnesium sulphate, } \\
\text { potassium chloride, } \\
\text { sodium chloride, } \\
\text { sodium sulphate }\end{array}$ & $\begin{array}{l}\text { Higher erosive impact for sodium sulphate, } \\
\text { followed by magnesium sulphate and potassium } \\
\text { chloride, with sodium chloride causing the lowest } \\
\text { impact. In general, higher erosive impact was } \\
\text { observed for solutions with higher content but the } \\
\text { results were not so clear for sodium chloride. }\end{array}$ \\
\hline $\begin{array}{l}\text { Scrivano and } \\
\text { Gaggero [19] }\end{array}$ & $\begin{array}{l}\text { Carbonate sedimentary } \\
\text { rocks }\end{array}$ & $\begin{array}{l}\text { Magnesium sulphate, } \\
\text { potassium nitrate, } \\
\text { sodium carbonate, } \\
\text { sodium chloride, } \\
\text { sodium sulphate }\end{array}$ & $\begin{array}{l}\text { More intense effects (powdering and breakage) for } \\
\text { sodium carbonate and sodium sulphate. Greater } \\
\text { mass loss values for sodium carbonate than for } \\
\text { sodium sulphate (around } 16 \times \text { times higher in one } \\
\text { case) but with a wide interval, from less than } 0.10 \% \\
\text { in both cases to around } 34 \% \text { for sodium sulphate and } \\
100 \% \text { for sodium carbonate. Magnesium sulphate } \\
\text { caused minor rounding and moderate swelling in } \\
\text { veins, with mass loss up to around } 2 \% \text {. Sodium } \\
\text { chloride and potassium nitrate solutions showed } \\
\text { surface crystallization of salts without significant } \\
\text { physical degradation (mass loss below } 0.20 \% \text { ). }\end{array}$ \\
\hline Zhao et al. [20] & Granite & $\begin{array}{l}\text { Magnesium sulphate, } \\
\text { sodium sulphate (both } \\
\text { with different contents) }\end{array}$ & $\begin{array}{l}\text { In both cases, higher mass loss for solutions with } \\
\text { higher salt content. Much higher values for sodium } \\
\text { sulphate (even so up to } 3.4 \% \text { ) than for magnesium } \\
\text { sulphate (just up to } 0.02 \% \text { ). }\end{array}$ \\
\hline
\end{tabular}


Table 2. Analysis of comparative studies of salt crystallization tests using seawater (as well as other salt solutions).

\begin{tabular}{|c|c|c|c|}
\hline Ref. & Rock Types & Solutions & Comparison \\
\hline Mottershead [21] & Schist & $\begin{array}{l}\text { Sodium chloride, } \\
\text { seawater }\left({ }^{1}\right)\end{array}$ & $\begin{array}{l}\text { Mass loss higher for sodium chloride solution than for } \\
\text { seawater }\left({ }^{2}\right)\end{array}$ \\
\hline Rivas et al. [22] & Granite & $\begin{array}{l}\text { Sodium chloride, } \\
\text { seawater }\end{array}$ & $\begin{array}{l}\text { Generally higher mass loss for the sodium chloride spray } \\
\text { (although, for the more porous granite type, there is a } \\
\text { certain overlap of values) also with some morphological } \\
\text { differences in terms of erosive features: granular } \\
\text { disintegration for sodium chloride and small scales for } \\
\text { seawater spray. }\end{array}$ \\
\hline Tingstad [23] & Limestone & $\begin{array}{l}\text { Sodium chloride, } \\
\text { sodium sulphate, } \\
\text { seawater }\end{array}$ & $\begin{array}{l}\text { The weathered surface was more irregular, achieving } \\
\text { both lower and higher depth, for sodium chloride than } \\
\text { for sodium sulphate or seawater (but the largest variation } \\
\text { was } 0.6 \mathrm{~mm}) \text {. }\end{array}$ \\
\hline Sitzia et al. [24] & $\begin{array}{l}\text { Sandstone, limestone, } \\
\text { marble, lavic rocks }\end{array}$ & $\begin{array}{l}\text { Rainwater, } \\
\text { groundwater, thermal } \\
\text { water, seawater (a } \\
\text { sequence of increasing } \\
\text { values of total } \\
\text { dissolved solids) }\end{array}$ & $\begin{array}{l}\text { For a given rock type, comparisons were only made } \\
\text { between rainwater and one of the other solutions, with } \\
\text { rainwater presenting lower mass loss in all cases but one } \\
\text { concerning specimens from a volcanic rock (rhyolite) } \\
\text { where mass loss with rainwater was higher than with } \\
\text { thermal water. The highest mass loss was observed in the } \\
\text { sandstone test with seawater (4.79\%). Photogrammetric } \\
\text { monitoring detected variations in the sandstone (both } \\
\text { with seawater and rainwater) and the two limestones } \\
\text { (with groundwater and rainwater). }\end{array}$ \\
\hline
\end{tabular}

\begin{abstract}
${ }^{1}$ The author considered solutions of other salts (calcium sulphate, magnesium bromide, magnesium chloride and magnesium sulphate) at the concentration of these salts in seawater (which is much lower than usually used in salt-weathering tests). ${ }^{2}$ The solutions of other salts at the concentration found in seawater caused much lower mass loss, with calcium sulphate being the more prominent, followed closely by magnesium sulphate.
\end{abstract}

Table 3. Analysis of comparative studies of salt crystallization tests that include mixtures of salts (excluding seawater).

\begin{tabular}{|c|c|c|c|}
\hline Ref. & Rock Types & Solutions & Comparison \\
\hline $\begin{array}{l}\text { Robinson and } \\
\text { Williams [25] }\end{array}$ & Sandstone & $\begin{array}{l}\text { Calcium sulphate, sodium } \\
\text { chloride, a mixture of these salts }\end{array}$ & $\begin{array}{l}\text { Higher mass loss for the mixture of sodium chloride } \\
\text { and calcium sulphate than for the solutions of these } \\
\text { salts, but values were generally below } 1.0 \% \text {. }\end{array}$ \\
\hline Cardell et al. [26] & Limestone & $\begin{array}{l}\text { Calcium sulphate, } \\
\text { magnesium sulphate }\end{array}$ & Cardell et al. [25] \\
\hline $\begin{array}{l}\text { DeClercq et al. } \\
\text { [27] }\end{array}$ & Limestone & $\begin{array}{l}\text { Sodium sulphate, a mixture of } \\
\text { this salt with sodium nitrate }\end{array}$ & $\begin{array}{c}\text { Sodium sulphate solutions produced lower mass loss } \\
\text { than the mixed solution. }\end{array}$ \\
\hline El-Gohary [28] & Limestone & $\begin{array}{l}\text { Sodium sulphate, mixtures of this } \\
\text { salt with other salts (sodium } \\
\text { chloride, iron chloride and } \\
\text { potassium nitrate) }\end{array}$ & $\begin{array}{l}\text { Solutions of sodium sulphate caused more damage to } \\
\text { the studied limestones than solutions with the same } \\
\text { concentration of this salt mixed with the other salts. }\end{array}$ \\
\hline Godts et al. [29] & Limestone & $\begin{array}{l}\text { Sodium sulphate, magnesium } \\
\text { sulphate, a mixture of these salts }\end{array}$ & $\begin{array}{l}\text { Erosive effects of solutions of sodium sulphate and } \\
\text { solutions of magnesium sulphate but not for mixed } \\
\text { solutions of these salts. }\end{array}$ \\
\hline $\begin{array}{l}\text { Menéndez and } \\
\text { Petráňová [30] }\end{array}$ & Limestone & $\begin{array}{l}\text { Calcium sulphate, sodium } \\
\text { chloride, sodium sulphate, a } \\
\text { mixture of these three salts }\end{array}$ & $\begin{array}{l}\text { A certain dispersion of results. In the crystallization } \\
\text { cycles, the specimens tested with the mixture did not } \\
\text { show as marked decay as with the worst cases with } \\
\text { either salt. Contrastingly, in relative humidity cycles, } \\
\text { all specimens subjected to the mixture presented } \\
\text { stronger decay, followed by those submitted to tests } \\
\text { with sodium chloride. Occurrence of gypsum at the } \\
\text { surface in the tests with calcium sulphate solutions } \\
\text { and inside the stones when mixed solutions of } \\
\text { calcium sulphate, sodium sulphate and sodium } \\
\text { chloride were employed. }\end{array}$ \\
\hline $\begin{array}{l}\text { Lindström et al. } \\
{[31]}\end{array}$ & Sandstone & $\begin{array}{l}\text { Sodium nitrate, sodium sulphate, } \\
\text { a mixture of these salts }\end{array}$ & $\begin{array}{c}\text { Mixed solutions caused higher erosion than sodium } \\
\text { nitrate solutions but lower than sodium } \\
\text { sulphate solutions. }\end{array}$ \\
\hline$\underset{\text { [32] }}{\text { Lindström et al. }}$ & Sandstone & $\begin{array}{l}\text { Magnesium sulphate, sodium } \\
\text { sulphate, mixture of magnesium } \\
\text { sulphate and sodium sulphate }\end{array}$ & Lindström et al. [31] \\
\hline
\end{tabular}

The set of rocks tested in these studies is ample but sedimentary rocks (limestone and sandstone) are clearly dominant, followed by pyroclastic rocks. This converges with results 
from our recent survey of salt-weathering tests focused on geological features, where these rocks (especially limestones and sandstones) were clearly dominant. Metamorphic rocks are relatively rare, with only one study considering results from marble specimens and another from schists. Granite, another important building stone type, is also poorly represented (with only two studies).

Sodium sulphate is the dominant salt in these studies and, based on previous reviews and the data in these tables, the erosive potential for sodium sulphate can be considered well-established. This salt is indeed used in many standards, such as the European EN 12370 , and it is dominant in the global set of laboratory studies of salt weathering. Nonetheless, there are some situations where it seems to have a less marked effect, situations that present a certain lithological variety (sandstone, limestone and pyroclastic rocks).

The information about the other salts is less straightforward, although the damaging potential of magnesium sulphate and sodium carbonate seems to be common. The question of the apparently lower erosive effects of sodium chloride and calcium sulphate in laboratory tests is a particularly relevant issue given the frequent occurrence of these salts in field cases. The lower damage caused by sodium chloride and calcium sulphate has been already highlighted by Goudie and Viles (1997) and we will pay specific attention to these salts in other sections below.

In most of the studies that compared seawater with other salt solutions, the former caused lower physical degradation (seawater, which is mostly sodium chloride, will be also included in the discussion in the next section). Concerning other salt mixtures, one can highlight that, frequently, solutions with sodium sulphate cause more damage than the solutions where this salt is mixed with others.

\section{On Sodium Chloride and Seawater}

The results presented in the tables of this work showed some examples where sodium chloride (and seawater) causes significant damage. One can find other indications of the erosive potential of sodium chloride in laboratory studies concerning a diversity of rock types, which will be discussed next.

The study of Smith and McGreevy, published in 1983 and reviewed by Goudie and Viles [5], dealing with sandstones and solutions of sodium sulphate, magnesium sulphate and sodium chloride, while showing higher erosive effects for sodium sulphate and magnesium sulphate, also mentioned erosive effects for sodium chloride.

Slight erosive effects (including some flaking) were obtained in sodium chloride tests in sandstone by McSkimming [33]. A study with two limestones by Al-Omari et al. [34] found mass losses that were slightly above $5 \%$ for one of them, but results were clearly affected by the mass of crystallized salt (in several tests, there was mass gain). Zalooli et al. [35] reported mass loss around $9 \%$ and 3\% for two limestone (travertine) types that showed, respectively, granular disintegration and significant fracturing (which might not be associated with marked weight loss as there was no separation from the specimen body).

Granites subjected to spray with sodium chloride solution showed erosion and oxidation stains, but the mass loss was not higher than $0.23 \%$ (Borges [36]). Silva and Simão [37], in tests with limestones, marbles and plutonic rocks using a spray of sodium chloride solution, found erosive effects and mass loss values that reached up to around $5 \%$ in limestone but were not higher than $1.0 \%$ in the specimens of marbles and plutonic rocks. Silva et al. [38] performed spray tests with sodium chloride solutions in plutonic rocks, obtaining erosive effects with increasing roughness and mass loss higher for hammered surfaces (but, even so, the maximum mass loss was around 1.1\%). Carvalho et al.'s [39] tests of limestones with a spray of sodium chloride solution showed mass loss values that were not higher than $0.40 \%$.

In the study of Goudie in 1974 (cited in Goudie and Viles [5]), sea brine caused mass loss values lower than some salts (sodium sulphate, sodium carbonate and calcium chloride) but higher than others (sodium carbonate and sodium nitrate) for sandstones, while for the limestone specimens, sea brine caused lower mass loss than sodium sul- 
phate, sodium carbonate, sodium nitrate and calcium chloride but higher than magnesium sulphate, calcium sulphate and sodium chloride.

While not very frequent nowadays, exposition tests, where the material is exposed to the weathering factors in the field, can be seen as something between laboratory tests and field studies (these exposure tests were already recommended by Vitruvius to test the suitability of a given stone for a given place [40]). Goudie et al. [41] report intense erosive effects of limestone blocks exposed for two years in the desert and associated with high halite content resulting from the desert saline fog. The study by Cabello-Briones and Viles [42] exposed blocks of limestone (which were previously washed in water to remove salts potentially present) in shelters (isolated from the ground) in a coastal location in Malta. These blocks showed surface erosive features after a year of exposition (one might admit that, given the location of the study, these erosive features are essentially the result of salts from sea spray, either newly deposited or previously inside the blocks and that were not removed by the washing operations).

\section{Regarding Calcium Sulphate}

Laboratory tests have not been clearly supportive of the erosive effect of calcium sulphate (and gypsum) resulting from this salt crystallization from migrating solutions (we are not considering here the effects associated with gypsum formation from $\mathrm{SO}_{2}$ tests). However, the tests of limestones subjected to calcium sulphate in the study of 1974 by Goudie (reviewed in Goudie and Viles [5]) gave a mass loss around 15\% (less than other salts but more than sodium chloride and wetting-drying with water).

Crystallization tests with calcium sulphate have promoted the development of subefflorescences and intergranular fissures parallel to the surface in limestones (Cardell et al. [26]). Moreover, using calcium sulphate solutions, Menéndez and David [43], Janvier-Badosa et al. [44], and Menéndez and Petráňová [30], all with limestones, and Rivas Brea et al. [45] with granites, did not observe erosive features (only gypsum crystallization). Janvier-Badosa et al. [44] mention previous works by Pauly in 1990 and Prick in 1996 that also only found gypsum crystallization at the surface.

Nonetheless, besides the scarce evidence for erosive effects of gypsum, it is interesting to note that Menéndez and David [43] reported gypsum crystallization below the surface and Menéndez and Petráňová [30] detected the occurrence of gypsum at the surface in the tests with calcium sulphate solutions and inside the stones when mixed solutions of calcium sulphate, sodium sulphate and sodium chloride were employed.

The question of crystallization below the surface is particularly relevant given the observation of this situation in field studies (e.g., Wendler et al. [46]; Jeannette [47]; Alves and Sequeira Braga [48]; Janvier-Badosa et al. [44,49]) and the prediction of this kind of distribution pattern in the model of Hammecker [50]. Besides the studies of natural stone as a building material, crystallization of gypsum has been associated with disruptive processes of building foundations (Yamanaka et al. [51]; Matheson and Quigley [52]).

Goudie and Viles [5] discuss factors that might contribute to the different assessments, on the erosive effects of gypsum, from field and laboratory studies, pointing to the influence of the presence of other salts, which can increase gypsum solubility due to ionic strength effects, promote crystallization cycles by deliquescence and affect the hydration state.

Salt-weathering tests are performed without regard to biological components and their conditions imply an almost sterile environment. However, there have been studies showing the interaction between organisms and gypsum (Sheikholeslami and Lau [53]). This could be an interesting avenue of research in terms of simulating the impact of gypsum on stone decay.

\section{Replication Crisis, Case Study Culture/Curse and Some Methodological Suggestions}

The replication or reproducibility crisis is a major contemporary concern that has received greater attention in the social and medical sciences but that could affect many other areas (Baker [54]). The culture/curse question could be seen as a provocation unsuitable in 
a research journal, but we contend that it is a prompt for a reflection on a relevant issue in the specific context of stone weathering studies. The term "curse" will suggest that it is an inevitable consequence, while culture suggests that it can be changed. At this point, we favor the latter option, but we are not closed-minded about the subject; while we think it is an important discussion to start, we do not think that we are, yet, in a position to offer a judgment.

One could suppose that laboratory studies are in a better position for replication than field studies, as they follow specific controlled protocols. However, the data collected above paint a more complex scenario. Namely, variations between rock types could imply a situation of a new case study for each newly studied rock type. Additionally, there could be significant variations within a certain "rock type". Giving an example, about which the present authors have some empirical evidence, "weathered granite" specimens with similar grain size and mineralogical composition could have significant variations in water migration properties, due to variations in weathering intensity, even in specimens from the same boulder, which will influence the results of salt-weathering tests.

The use of different testing conditions, in terms of imbibition conditions and drying conditions, while having the potential to shed some light on the influence of different factors, can contribute also to a case study culture.

These considerations lead us to propose two major methodological suggestions:

- $\quad$ always use a random selection of specimens;

- $\quad$ report detailed information on each of the specimens studied;

- have a baseline of testing conditions for comparison.

The first point is a well-known basis for any statistical study. It should guide the distribution of the specimens between the groups ("treatments") that are to be compared. For a good implementation of this principle, one should prepare a higher number of specimens than those that are going to be tested (the ones to be tested will be randomly selected from the initial set of specimens).

Concerning the second issue, the detailed information for each specimen studied should include a detailed description, at least at the macroscopic level but ideally also including thin sections from the portions adjacent to the specimen, non-destructive measurements before the testing and individual test results. The development of non-destructive imaging techniques such as X-ray tomography could offer an important contribution in this regard.

Lastly, while creativity in terms of testing conditions promotes a vibrant research culture in terms of the influence of different factors, it will be useful to perform, at the same time, testing under the conditions proposed in the present standards given that this will allow the comparison with a much wider set of results.

\section{Implications: Hazard Assessment (with Reference to the Comparison with Field Studies) and Conservation Procedures}

Assessing the risk posed by salt weathering to stone heritage requires evaluating the possibility of the occurrence of the problem-in this case of the salt pollutants-and the impact that the occurrence of the pollutants will pose to the affected item. Regarding salt weathering, this means not only to assess the differential impact of different salt compositions but also to assess the geochemical conditions, i.e., the possibility of the occurrence of the salts.

Field studies could be considered a "reality check" on the results of salt-weathering simulations. However, there are complexities, sometimes insurmountable, that hinder this goal. Namely, environmental conditions are variable over time and, in general, there is a marked absence of data concerning these variations. Besides the problems of establishing the sources of pollutants, it is troublesome to assess the presence and contents of the pollutants. Salt efflorescences are a clear marker that are relatively easy to characterize (but there could be diverse space variations). One should also remember the often-quoted principle that association does not mean causation. In this case, the salts crystallizing inside 
the stone material (and causing the erosion) might be significantly different from the ones at the surface, e.g., due to different solubilities (see discussion by Hammecker [50]). One can also suggest that it might be useful to develop more research on modern buildings (which have had a clear subordinate position when compared to historical heritage in terms of research, but which might constitute case studies with better-constrained characteristics).

Nonetheless, field studies could be an important source of information regarding the frequency of occurrence of the pollutants (the geochemical hazard, so to speak). Among the diverse salts considered, sodium chloride has a well-known wide distribution and, as mentioned above, calcium sulphate (gypsum) is frequently found in diverse field studies. Thenardite is a major phase in recent structures (Alves [55]) and, accepting the hypothesis that its occurrence is related to the presence of modern cements (Arnold and Zehnder [3]), it will be another argument to be mindful of the use of these substances in restoration works.

These studies could also have significant relevance for the conservation measures to be undertaken. While, in general, research publications are focused on showing and highlighting the damaging effects, tests where the salts do not cause visible alterations arguably deserve greater attention as they could suggest situations that minimize the impact of salt pollution and, therefore, it will be important to use rock materials that present the highest susceptibility to salt weathering under standard conditions. This point highlights one of the issues of the last section (comparison between testing conditions). Field studies could be also useful in this respect when soluble salts are found (on efflorescences) without causing significant stone erosion, although, again, one should keep in mind the problem of the characterization of the field conditions through time, leading to this result.

\section{Final Considerations}

The question of which salts have the greatest erosive impact on materials such as natural stone has been the object of multitudinous laboratory studies. There are several results pointing to the major effects of salts such as sodium sulphate, magnesium sulphate and sodium carbonate and suggesting comparatively minor effects for other salts such as sodium chloride and gypsum. Results for other salts, including mixtures, are less clear.

However, the assessment of salt-weathering hazards in the anthropogenic environment should also consider the abundance of the specific salts. While, in laboratory saltweathering tests, sodium chloride is, generally, not as aggressive as other salts (namely sodium sulphate), there are indications from these tests showing that this salt can have the potential for provoking erosive damage to natural stone. The frequent association of sodium chloride with erosive effects is supported by its abundance in the anthropogenic environment due to contributions from sea-related sources (sea spray, seawater, which can contaminate, also, neighboring groundwater) to which one can add the contributions of de-icing salts and also other uses from historical times (that affect historical structures but might also affect new ones built on contaminated grounds), such as the storage of common salt.

A more complex situation concerns the case of gypsum. A combination of geochemical abundance (several sources) and relatively low solubility (compared with other soluble salts that crystallize by evaporation) promotes opportunities for its crystallization, and, indeed, gypsum is frequently identified in erosive decay features of natural stone. However, laboratory tests, in general, have not shown marked erosive effects for this salt (but there are some results in this direction). It could help to elucidate this issue through the performance of tests under conditions more similar to those found in the built environment. These tests should consider, namely, the size of the elements, the composition of solutions (both in terms of inorganic and organic constituents), the way the solutions migrate through the stone and also the number of testing cycles, since crystallization cycles could be very frequent in historical structures due to pore water flow as a consequence of rainwater events (followed by drying) and to the presence of other deliquescent salts. 
While the methodological suggestions presented above could be considered to correspond to ideal situations hardly achievable at the present time, we think that they could guide future research.

The review of these results suggests the possibility of replication problems related to a proliferation of case studies resulting from the issues associated with variations in natural stone characteristics. Suggestions to minimize this issue concern statistical considerations (random selection of specimens) and the need for detailed characterization and reporting of results for each specimen (to assess variation).

We propose that there are significant implications from the results reviewed here and information from field studies in terms of hazard assessment and conservation intervention. Sodium sulphate is a common salt in modern structures and its potential link to modern cements could render it something to be wary of in terms of the use of this material. While sodium chloride and gypsum frequently were less damaging than sodium sulphate, their common occurrence in the field makes them relevant through a kind of geochemical hazard. Special attention should be given to results where salts caused low erosive damage, in the sense that they could suggest procedures for minimizing the impact of salt weathering (and, therefore, it could be especially useful to use materials that are more susceptible to salt weathering).

Author Contributions: All authors contributed, have read and agreed to the published version of the manuscript. All authors have read and agreed to the published version of the manuscript.

Funding: This specific research received no external funding (but please see the Acknowledgments).

Institutional Review Board Statement: Not applicable.

Informed Consent Statement: Not applicable.

Data Availability Statement: Not applicable.

Acknowledgments: The Lab2PT-Landscapes, Heritage and Territory laboratory-UIDB/04509/2020 is supported by the Portuguese FCT—“Fundação para a Ciência e a Tecnologia". The authors also gratefully acknowledge the support of the CERENA (funded by a strategic project of the FCTUIDB/04028/2020) and the LAMPIST of the DECivil, Instituto Superior Técnico, University of Lisbon, Portugal. The University Institute of Geology of the University of A Coruña (Spain) receives support from the Xunta de Galicia from the program "Consolidación y estructuración de unidades de investigación competitivas: Grupos de potencial de crecimiento" (ED431B 2018/47) and Redes de investigación (R2017/008).

Conflicts of Interest: The authors declare no conflict of interest.

\section{References}

1. Bertolin, C. Preservation of cultural heritage and resources threatened by climate change. Geosciences 2019, 9, 250. [CrossRef]

2. Macaulay, G.C. Herodotus. The History of Herodotus; MacMillan and Co.: London, UK; New York, NY, USA, 1890; Volume I, Available online: http:/ / www.gutenberg.org/ebooks/2707 (accessed on 27 June 2020).

3. Arnold, A.; Zehnder, K. Monitoring Wall Paintings Affected by Soluble Salts: The Conservation of Wall Paintings; Cather, S., Courtauld Institute of Art, Getty Conservation Institute, Eds.; Getty Conservation Institute: Marina del Rey, CA, USA, 1991 ; pp. $103-135$.

4. Nord, A.G. Efflorescence salts on weathered building stone in Sweden. Geol. Föreningen I Stockh. Förhandlingar 1992, 114, 423-429. [CrossRef]

5. Goudie, A.S.; Viles, H.A. Salt Weathering Hazards; John Wiley \& Sons: Chichester, UK, 1997.

6. Charola, A.E.; Bläuer, C. Salts in Masonry: An overview of the problem. Restor. Build. Monum. 2015, 21, 119-135. [CrossRef]

7. Doornkamp, J.C.; Ibrahim, H.A.M. Salt weathering. Prog. Phys. Geogr. Earth Environ. 1990, 14, 335-348. [CrossRef]

8. Charola, A.E. Salts in the deterioration of porous materials: An overview. J. Am. Inst. Conserv. 2000, 39, 327-343. [CrossRef]

9. Doehne, E. Salt weathering: A selective review. Geol. Soc. Lond. Spec. Publ. 2002, 205, 51-64. [CrossRef]

10. Oguchi, C.T.; Yu, S. A review of theoretical salt weathering studies for stone heritage. Prog. Earth Planet. Sci. 2021, 8, 32. [CrossRef]

11. Lubelli, B.; Cnudde, V.; Diaz-Goncalves, T.; Franzoni, E.; van Hees, R.P.J.; Ioannou, I.; Menendez, B.; Nunes, C.; Siedel, H.; Stefanidou, M.; et al. Towards a more effective and reliable salt crystallization test for porous building materials: State of the art. Mater. Struct. 2018, 51, 55. [CrossRef]

12. Yu, S.; Oguchi, C.T. Is sodium sulphate invariably effective in destroying any type of rock? Geol. Soc. Lond. Spec. Publ. 2010, 333, 43-58. [CrossRef] 
13. Heidari, M.; Torabi-Kaveh, M.; Mohseni, H. Assessment of the effects of freeze-thaw and salt crystallization ageing tests on Anahita temple stone, Kangavar, West of Iran. Geotech. Geol. Eng. 2017, 35, 121-136. [CrossRef]

14. Sato, M.; Hattanji, T. A laboratory experiment on salt weathering by humidity change: Salt damage induced by deliquescence and hydration. Prog. Earth Planet. Sci. 2018, 5, 84. [CrossRef]

15. Çelik, M.Y.; Aygün, A. The effect of salt crystallization on degradation of volcanic building stones by sodium sulfates and sodium chlorides. Bull. Eng. Geol. Environ. 2019, 78, 3509-3529. [CrossRef]

16. Derluyn, H.; Vontobel, P.; Mannes, D.; Derome, D.; Lehmann, E.; Carmeliet, J. Saline water evaporation and crystallizationinduced deformations in building stone: Insights from high-resolution neutron radiography. Transp. Porous Media 2019, 128, 895-913. [CrossRef]

17. Torabi-Kaveh, M.; Heidari, M.; Mohseni, H.; Ménendez, B. Role of petrography in durability of limestone used in construction of Persepolis complex subjected to artificial accelerated ageing tests. Environ. Earth Sci. 2019, 78, 1-18. [CrossRef]

18. Çelik, M.Y.; Sert, M. The role of different salt solutions and their concentration ratios in salt crystallization test on the durability of the Döğer tuff (Afyonkarahisar, Turkey) used as building stones of cultural heritages. Bull. Eng. Geol. Environ. 2020, 79, 5553-5568. [CrossRef]

19. Scrivano, S.; Gaggero, L. An experimental investigation into the salt-weathering susceptibility of building limestones. Rock Mech. Rock Eng. 2020, 53, 5329-5343. [CrossRef]

20. Zhao, F.; Sun, Q.; Zhang, W. Combined effects of salts and wetting-drying cycles on granite weathering. Bull. Eng. Geol. Environ. 2020, 79, 3707-3720. [CrossRef]

21. Mottershead, D.N. Rapid weathering of greenschists by coastal salt spray, east Prawle, south Devon: A preliminary report. Proc. Ussher Soc. 1982, 5, 347-353.

22. Rivas, T.; Prieto, B.; Silva, B.; Birginie, J.M. Weathering of granitic rocks by chlorides: Effect of the nature of the solution on weathering morphology. Earth Surf. Process. Landf. 2003, 28, 425-436. [CrossRef]

23. Tingstad, A. Simulation of salt weathering in a closely replicated coastal environment. Geogr. Ann. Ser. A Phys. Geogr. 2008, 90, 165-171. [CrossRef]

24. Sitzia, F.; Lisci, C.; Mirão, J. Accelerate ageing on building stone materials by simulating daily, seasonal thermo-hygrometric conditions and solar ra-diation of Csa Mediterranean climate. Constr. Build. Mater. 2021, 266. [CrossRef]

25. Robinson, D.A.; Williams, R.B.G. Experimental weathering of sandstone by combinations of salts. Earth Surf. Process. Landf. 2000, 25, 1309-1315. [CrossRef]

26. Cardell, C.; Benavente, D.; Rodríguez-Gordillo, J. Weathering of limestone building material by mixed sulfate solutions. Characterization of stone microstructure, reaction products and decay forms. Mater. Charact. 2008, 59, 1371-1385. [CrossRef]

27. DeClercq, H.; Jovanović, M.; Linnow, K.; Steiger, M. Performance of limestones laden with mixed salt solutions of $\mathrm{Na}_{2} \mathrm{SO}_{4}-\mathrm{NaNO}_{3}$ and $\mathrm{Na}_{2} \mathrm{SO}_{4}-\mathrm{K}_{2} \mathrm{SO}_{4}$. Environ. Earth Sci. 2013, 69, 1751-1761. [CrossRef]

28. El-Gohary, M. Physical deterioration of Egyptian limestone affected by saline water. Int. J. Conserv. Sci. 2013, 4, 447-458.

29. Godts, S.; Hendrickx, R.; De Clercq, H. The Crystallization Behavior of Sodium Magnesium Sulfate in Limestone, Proceedings of the 3rd International Conference on Salt Weathering of Buildings and Stone Sculptures (SWBSS 2014), Brussels, Belgium, 14-16 October 2014; Aedificatio Publishers: Brussels, Belgium, 2014; pp. 167-182.

30. Menéndez, B.; Petráňová, V. Effect of mixed vs single brine composition on salt weathering in porous carbonate building stones for different environmental conditions. Eng. Geol. 2016, 210, 124-139. [CrossRef]

31. Lindström, N.; Heitmann, N.; Linnow, K.; Steiger, M. Crystallization behavior of $\mathrm{NaNO}_{3}-\mathrm{Na}_{2} \mathrm{SO}_{4}$ salt mixtures in sandstone and comparison to single salt behavior. Appl. Geochem. 2015, 63, 116-132. [CrossRef]

32. Lindström, N.; Talreja, T.; Linnow, K.; Stahlbuhk, A.; Steiger, M. Crystallization behavior of $\mathrm{Na}_{2} \mathrm{SO}_{4}-\mathrm{MgSO}_{4}$ salt mixtures in sandstone and comparison to single salt behavior. Appl. Geochem. 2016, 69, 50-70. [CrossRef]

33. McSkimming, E. Weathering effects on the engineering properties of Sydney (Yellow Block) sandstone when used as a building material. Int. J. Archit. Herit. 2015, 9, 497-509. [CrossRef]

34. Al-Omari, A.; Beck, K.; Brunetaud, X.; Al-Mukhtar, M. Assessment the stones compatibility based on salt weathering tests. Zanco J. Pure Appl. Sci. 2019, 31 (Suppl. s3), 75-83.

35. Zalooli, A.; Khamehchiyan, M.; Nikudel, M.R. Durability assessment of Gerdoi and red travertines from Azarshahr, East Azerbaijan province, Iran. Bull. Eng. Geol. Environ. 2019, 78, 1683-1695. [CrossRef]

36. Borges, M.I.; Simão, J.; Silva, Z. Artificial weathering of Portuguese granites exposed to salt atmosphere: Variations of physicomechanical properties. In Proceedings of the Conference "Salt Weathering on Buildings and Stone Sculptures", Limassol, Cyprus, 19-22 October 2011; Volume 19, pp. 22-30.

37. Silva, Z.S.G.; Simão, J.A.R. The role of salt fog on alteration of dimension stone. Constr. Build. Mater. 2009, 23, 3321-3327. [CrossRef]

38. Silva, Z.C.G.; Simão, J.A.R.; Sá, M.H.; Leal, N. Rock finishing and response to salt fog atmosphere. Key Eng. Mater. 2013, 548, 275-286. [CrossRef]

39. Carvalho, C.; Silva, Z.; Simão, J. Evaluation of Portuguese limestones' susceptibility to salt mist through laboratory testing. Environ. Earth Sci. 2018, 77, 523. [CrossRef]

40. Vitruvius. The Ten Books on Architecture; Translated by Morris Hicky Morgan; Harvard University Press: Cambridge, MA, USA, 1914; Available online: http:/ / www.gutenberg.org/ebooks/20239 (accessed on 27 June 2020). 
41. Goudie, A.S.; Viles, H.A.; Parker, A.G. Monitoring of rapid salt weathering in the central Namib Desert using limestone blocks. J. Arid Environ. 1997, 37, 581-598. [CrossRef]

42. Cabello-Briones, C.; Viles, H.A. Evaluating the effects of open shelters on limestone deterioration at archaeological sites in different climatic locations. Int. J. Archit. Herit. 2017, 11, 816-828. [CrossRef]

43. Menéndez, B.; David, C. The influence of environmental conditions on weathering of porous rocks by gypsum: A non-destructive study using acoustic emissions. Environ. Earth Sci. 2013, 68, 1691-1706. [CrossRef]

44. Janvier-Badosa, S.; Beck, K.; Brunetaud, X.; Guirimand-Dufour, A.; Al-Mukhtar, M. Gypsum and spalling decay mechanism of tuffeau limestone. Environ. Earth Sci. 2015, 74, 2209-2221. [CrossRef]

45. Rivas Brea, T.; Prieto Lamas, B.; Silva Hermo, B. Artificial weathering of granite. Mater. Construcción 2008, 58, 289-290. [CrossRef]

46. Wendler, E.; Klemm, D.D.; Snethlage, R. Contour scaling on building facades-Dependence on stone type and environmental conditions. MRS Online Proc. Libr. 1990, 185, 265-271. [CrossRef]

47. Jeannette, D. Morphologie et nomenclature des alterations. In La Conservation de la Pierre Monumentale en France; Presses du CNRS: Paris, France, 1992; pp. 51-72.

48. Alves, C.A.S.; Sequeira Braga, M.A. Decay effects associated with soluble salts on granite buildings of Braga (NW Portugal). In Environmental Mineralogy: Microbial Interactions, Anthropogenic Influences, Contaminated Land and Waste Management; Cotter-Howells, J.D., Campbell, L.S., Valsami-Jones, E., Batchelder, M., Eds.; Mineralogical Society of Great Britain \& Ireland: Middlesex, UK, 2000; pp. 181-199.

49. Janvier-Badosa, S.; Beck, K.; Brunetaud, X.; Al-Mukhtar, M. The occurrence of gypsum in the scaling of stones at the Castle of Chambord (France). Environ. Earth Sci. 2014, 71, 4751-4759. [CrossRef]

50. Hammecker, C. The importance of the petrophysical properties and external factors in the stone decay on monuments. Pure Appl. Geophys. 1995, 145, 337-361. [CrossRef]

51. Yamanaka, T.; Miyasaka, H.; Aso, I.; Tanigawa, M.; Shoji, K.; Yohta, H. Involvement of sulfur- and iron-transforming bacteria in heaving of house foundations. Geomicrobiol. J. 2002, 19, 519-528. [CrossRef]

52. Matheson, G.D.; Quigley, P. Evaluating pyrite-induced swelling in Dublin mudrocks. Q. J. Eng. Geol. Hydrogeol. 2016, 49, 47-66. [CrossRef]

53. Sheikholeslami, R.; Lau, G.T. Effect of bacteria and salinity on calcium sulfate precipitation. Desalination 2012, 287, 301-309. [CrossRef]

54. Baker, M. 1500 scientists lift the lid on reproducibility. Nature 2016, 533, 452-454. [CrossRef] [PubMed]

55. Alves, C. Scanning electron microscopy studies of neoformations on stony materials of modern building works. Microsc. Microanal. 2013, 19, 1241-1247. [CrossRef] [PubMed] 